\title{
Respiratory health of cigar factory workers
}

Jukka Uitti, Henrik Nordman, Matti S Huuskonen, Pekka Roto, Kaj Husman, Marjut Reiman

\begin{abstract}
Objectives-To determine whether occupational exposure to raw tobacco causes respiratory or allergic diseases, an excess of respiratory symptoms, a decrease in lung function, or parenchymal changes in chest radiography among Finnish cigar workers.

Methods-This cross sectional study included all Finnish cigar workers $(n=106)$ exposed to raw tobacco and also a group of unexposed matched referents. Data were collected with a self administered questionnaire, flow volume spirometry, measurements of diffusing capacity of the lung for carbon monoxide, chest radiography and skin prick tests. A questionnaire was also sent to former workers of the factory.
\end{abstract}

Results-There were no significant differences between the groups in the prevalence of respiratory symptoms and chest radiography findings. Nine of 102 tobacco workers had pulmonary fibrosis of at least $1 / 0$ (according to the International Labour Organisation (ILO) 1980 classification) and the corresponding figure was five for the referents. The tobacco workers tended to have a low forced vital capacity (FVC), and they had impaired forced expiratory volume in 1 second and lower means of the maximal expiratory flow at $25 \%$ of the FVC significantly more often than the referents. Diffusing capacity tended to be lower among the referents. The referents more often had atopy and earlier atopic diseases than the exposed workers. These results indicate the possibility of selection among the exposed workers.

Conclusions-No excess of prevalence of respiratory symptoms in the tobacco workers was found. According to the questionnaire episodes of allergic alveolitis may have occurred in the cigar factory workers. However, in the absence of impairments in lung function and radiological changes it was not possible to distinguish humidifier fever and allergic alveolitis. In exposure conditions that include humidification of the air humidifier, fever and allergic alveolitis constitute a risk for tobacco workers. No effects were shown of exposure to tobacco dust on lung function.

(Occup Environ Med 1998;55:834-839)

Keywords: tobacco dust; lung function; occupational exposure
Raw tobacco dust can contain bacteria, endotoxins, and fungal spores (moulds), pollen, mites, insects, particulates, of inorganic materials such as quartz, and residues of pesticides or insecticides. ${ }^{1}$ The cigar process depends on constant humidity; the working environment is humidified and creates conditions for microbial growth. Increased concentrations of microorganisms including moulds, bacteria and endotoxins have been measured in the tobacco industry. ${ }^{23}$ Concentrations of moulds may be similar to those of buildings with prolonged moisture problems. ${ }^{3-5}$ These microorganisms and their metabolites, found also in damp workplaces, are known to cause symptoms of irritation, hypersensitivity reactions, or allergic diseases. ${ }^{6}$ Also the tobacco leaf itself consists of proteins that can act as allergens ${ }^{7}$ that produce immunoglobulin $\mathrm{E}$ ( $\mathrm{IgE}$ ) antibodies in exposed workers. ${ }^{8}$ One case of sensitivity to tobacco leaf mediated by $\operatorname{IgE},^{8}$ one case of allergic alveolitis, and a late asthmatic reaction caused by fungi (Scopulariopsis brevicaulis) from tobacco leaves ${ }^{9}$ have been published. Increased concentrations of angiotensin converting enzyme (ACE) and lysosomal enzymes have been found in tobacco workers, ${ }^{10}$ and bronchoalveolar lavages have shown similar findings of phagocytosing macrophages in tobacco workers as in grain workers. ${ }^{11}$ Both findings may indicate allergic or toxic reaction. ${ }^{10}$ Therefore tobacco dust can be assumed to have toxic, irritative, or immunogenic properties. ${ }^{12}$

A significant decrease in forced expiratory volume in 1 second $\left(\mathrm{FEV}_{1}\right)$ during the workshift and an excess of chest tightness have been reported among non-smoking tobacco workers. $^{13}$ Obstruction of the airways of tobacco workers has been suggested by several research groups. ${ }^{12}{ }^{14-17}$ Findings have not been conclusive mainly due to difficulties in controlling the confounding effect of smoking or selection. Irritant symptoms of the eyes were reported at comparatively low exposure concentrations in tobacco workers $\left(1.26 \mathrm{mg} / \mathrm{m}^{3}\right.$ total dust). ${ }^{18}$

In one study $26 \%$ of the examined tobacco workers claimed to have work related respiratory symptoms, and three workers were considered to have allergic alveolitis. ${ }^{19}$

To further study the possible health effects of tobacco dust, we chose cigar factory workers exposed to raw tobacco. Our objective was to assess the prevalence of respiratory symptoms, impaired lung function, and parenchymal changes in chest radiography among the workers.

Conditions of industrial hygiene in the particular cigar factory have been studied. ${ }^{3}$ The total dust concentrations in the air of the 
Table 1 Characteristics of the study groups

\begin{tabular}{|c|c|c|}
\hline Characteristics & Tobacco workers $(n=106)$ & Referents $(n=106)$ \\
\hline $\mathrm{n}$ & 106 & 106 \\
\hline \multicolumn{3}{|l|}{$\operatorname{Sex}(n)$ : } \\
\hline $\mathrm{F}(\%)$ & 75 & 75 \\
\hline$M(\%)$ & 25 & 25 \\
\hline \multicolumn{3}{|l|}{ Age (y): } \\
\hline Mean $(95 \%$ CI) & 46 (44 to 47$)$ & 46 (44 to 47$)$ \\
\hline Range & $30-61$ & $29-63$ \\
\hline \multicolumn{3}{|l|}{ Duration of employment (y): } \\
\hline Mean $(95 \% \mathrm{CI})$ & $21(19$ to 23$)$ & $15(14$ to 17$)$ \\
\hline Range & $9-42$ & $1-39$ \\
\hline \multicolumn{3}{|l|}{ Height $(\mathrm{cm})$ : } \\
\hline Mean $(95 \% \mathrm{CI})$ & $166(164$ to 167$)$ & $166(165$ to 168$)$ \\
\hline Range & $152-184$ & $152-182$ \\
\hline \multicolumn{3}{|l|}{ Weight (kg): } \\
\hline Mean $(95 \% \mathrm{CI})$ & $70(68$ to 72$)$ & $67(65$ to 70$)$ \\
\hline Range & $51-98$ & $45-110$ \\
\hline \multicolumn{3}{|l|}{ Smoking (\%): } \\
\hline Non-smoker & 41.5 & 41.5 \\
\hline Ex-smoker & 23.6 & 23.6 \\
\hline Current smoker & 34.9 & 34.9 \\
\hline \multicolumn{3}{|l|}{ Cumulative smoking (pack-years): } \\
\hline Ex-smokers (mean $(95 \% \mathrm{CI})$ ) & $16(11$ to 21$)$ & $9(6$ to 12$)$ \\
\hline Current smokers (mean $(95 \% \mathrm{CI})$ ) & $14(11$ to 17$)$ & $17(12$ to 22$)$ \\
\hline
\end{tabular}

factory were lower than the hygienic limit of 5 $\mathrm{mg} / \mathrm{m}^{3}$ usually applied for organic materials. The highest total dust concentrations were measured during the opening of the tobacco bales $\left(4.5 \mathrm{mg} / \mathrm{m}^{3}\right)$. The geometric mean of the concentration of mesophilic bacteria was 68 $707 \mathrm{cfu} / \mathrm{m}^{3}$ (cfu=colony forming units) and that of the xerotolerant fungi was $7962 \mathrm{cfu} / \mathrm{m}^{3}$. In the cigar factory the ventilation system was also heavily contaminated with bacteria. Endotoxin concentrations in the air varied between 13 and $38 \mathrm{ng} / \mathrm{m}^{3}$ in the cigar factory. ${ }^{3}$

\section{Subjects and methods}

CHARACTERISTICS OF THE SUBJECTS

All workers in Finnish cigar production were asked to participate in the study because the exposure to handled raw material remained unchanged during the manufacturing process. ${ }^{3}$ They all accepted. Controls were matched for confounding factors. We expected to find a high prevalence of current and former smoking among the tobacco workers because they were allowed to use the product freely throughout the working day. A matched reference group of the same size was chosen from a non-exposed population, mainly from local office workers of other workplaces, banks, offices of enterprises, and the community, and from the staff of the town library. The reference group also included 26 blue collar workers from other workplaces without exposure to irritative or sensitising agents - that is, storing or transporting operations. Only two of the invited referents refused, because of lack of time.

The following matching criteria were used: sex, age ( \pm 3 years) and smoking category (smoker, non-smoker, ex-smoker). Four did not fulfil the matching criteria; therefore the final number of matched pairs was 106. The matched populations were comparable, except for the duration of employment (table 1). Earlier exposure to asbestos, dusts, other irritants, and sensitisers were distributed evenly in both groups. The questionnaire asked about packyears of smoking. According to the pack-years of smoking calculated for the ex-smokers (table 1), the tobacco workers had smoked longer and daily more often than the referents, whereas among current smokers the workers had less pack-years than the referents. The occurrence of diseases and the use of medication were distributed similarly in both groups.

The field study was carried out in the winter before the beginning of the spring pollen season. ${ }^{20}$ It was impossible to blind the study personnel as to the exposed-unexposed status of the subjects. A separate questionnaire was sent to 121 former workers who had left or retired during the 5 years immediately preceding the study. Sixty four per cent $(n=77)$ of the formerly exposed people responded.

\section{METHODS}

The tobacco workers and their referents completed a self administered questionnaire about personal characteristics, respiratory symptoms, smoking habits, occupational history, and a personal and family history of allergy, medication, pulmonary diseases, and other diseases. The questionnaire was based on the questionnaire of the Medical Research Council (MRC). ${ }^{21}$ Questions about allergic alveolitis and algorithms were the same as used by Terho $e t a l^{2}$ in studies of allergic alveolitis among Finnish farmers. Only minor modifications to the questions made adjustments for the tobacco industry. Thus a respondent was classified as having alveolitis if he or she had prolonged cough, dyspnoea, or fever during working periods. The symptoms had to appear or worsen at work or in different working tasks. Also, the symptoms should have occurred some time after but not immediately after, the work had begun. The formerly exposed workers were asked about symptoms occurring during their working period and about earlier allergies. Current health and reasons for having left their jobs in the plant were also inquired about.

The reliability of the questionnaire was assessed by asking 75 of the workers to fill out the questionnaire again 3 weeks later. The questions on the key symptoms (asthma, alveolitis, and chronic bronchitis) had a reliability ranging between $88 \%$ and $92 \%$. Workers who had smoked at least one cigarette a day for a minimum of 1 year and who had smoked during the past 6 months were considered to be smokers. Ex-smokers had not smoked during the past 6 months. Nonsmokers had never smoked at least one cigarette a day during a period of 1 year or more.

Spirometric measurements were taken from each subject by means of a computerised flowvolume spirometer (Medikro 101, Medikro, Finland), according to the standards of the American Thoracic Society. ${ }^{23}$ The spirometer was calibrated twice each day with a 51 syringe. From the curves of the maximal expiratory flow (MEF) volume, the highest FVC and $\mathrm{FEV}_{1}$ were measured. All the values were also expressed as the percentages of the predicted values in Finland. ${ }^{24}$ The test was performed by trained personnel, and their test results were regularly assessed for reliability. 
Table 2 Odds ratios (ORs) for respiratory symptoms in the tobacco workers (OR based on McNemar's test of 106 matched pairs)

\begin{tabular}{lll}
\hline Symptoms & OR & (95\% CI) \\
\hline Cough & 1.3 & $(0.3$ to 4.7$)$ \\
Phlegm & 0.7 & $(0.2$ to 1.9$)$ \\
Chronic bronchitis & 0.4 & $(0.1$ to 1.4$)$ \\
Shortness of breath & 1.2 & $(0.4$ to 3.5$)$ \\
Wheezing & 0.3 & $(0.0$ to 2.9$)$ \\
Symptoms of alveolitis & 1.0 & \\
Rhinitis & 0.6 & $(0.3$ to 1.2$)$ \\
Eye complaints & 0.5 & $(0.2$ to 0.9$)$ \\
\hline
\end{tabular}

The diffusing capacity of the lung for carbon monoxide $\left(\mathrm{D}_{\mathrm{LCO}}\right)$ was measured with the Morgan transfer test and the single breath method. At least two successful consecutive measurements were performed, and the mean value of the two nearest test results was chosen. ${ }^{25}$ The $D_{\text {LCO }}$ values and the specific diffusing capacity $\left(\mathrm{D}_{\mathrm{LCO}} / \mathrm{VA}\right)$ were adjusted to the real time haemoglobin measurement. ${ }^{26}$ The observed results were also expressed as the percentages of the values predicted for Finland. ${ }^{24}$ Two trained laboratory technicians performed the $\mathrm{D}_{\text {LCO }}$ measurements.

Immunoglobulin $\mathrm{G}$ antibodies (IgGs) to moulds were analysed from the blood samples of cigar factory workers and referents. The panel used was based on those microorganisms found in the cigar factory during the hygienic study. ${ }^{3}$

Tobacco extracts were prepared from the following tobacco species: Java, Kamerun, Brasil, Colombia, Havana, Java (cover leaf), and a mixture of nine tobacco sorts (Allergologisk Laboratorium A/S, Copenhagen, Denmark). As well as these seven tobacco extracts 12 commercial glycerol-saline extracts were used (Allergologisk Laboratorium A/S, Copenhagen, Denmark). The seven common environmental allergens were timothy, birch, mugworth, dog, cat, house dust mite, (Dermatophagoideus pteronyssimus), and Cladosporium (10 histamine equivalent pricks (HEPs)). The extracts used from moulds and fungi were Candida albicans, Alternaria alternata, Aspergillus fumigatus, Aspergillus niger, and Mucor racemocus (dilution 1:20). Skin tests were carried out with the standardised skin prick method with a disposable needle. ${ }^{27}$ The same trained nurse carried out all the tests, and a trained specialist in pulmonary medicine read all the results 15-20 minutes after the pricking. The greatest diameter and the diameter perpendicular to it were measured for each weal. The mean of these diameters was the test result. A test was positive if the mean of the diameters in the test was equally $\geqslant 3 \mathrm{~mm}$. The skin prick tests were performed on the subjects 1.5 years after the other cross sectional examinations were made. A person was considered atopic if he or she had at least one positive skin test to common environmental allergens.

In the radiographic examination $35 \times 35 \mathrm{~cm} x$ ray film was used. Chest $x$ ray films were taken from 102 cigar workers and 99 referents. The posteroanterior radiographs were read according to the classification of the International Labour Organisation (ILO). ${ }^{28}$ Two radiologists, both of whom were experienced with the
ILO system, read the films independently with no knowledge of the subjects. If the assessments did not agree, the films were reviewed by the readers together and the score was determined jointly as the classification recommends. The reliability of the classifications was determined from the independent classifications ( $\kappa 0.77$ ).

Basic statistics were used to describe the data. The frequency tables were analysed with $\chi^{2}$ statistics. The relative risks (odds ratios (ORs)) for the discrete variables were based on the $\chi^{2}$ value of the McNemar test, which compares disparate pairs. When the relations between pulmonary function and exposure were studied, we used the paired Student's $t$ test and analysis of covariance (ANCOVA). The effects of height and pack-years of smoking on the spirometric variables, and the effects of height, weight, and pack-years on diffusing capacity were taken into account as covariates. As a covariate pack-years of smoking was transformed logarithmically in the analysis. SAS statistical software was applied (SAS Institute, USA).

\section{Results}

SYMPTOMS

The prevalence of respiratory symptoms did not differ significantly between the exposed and unexposed groups (table 2). The referents had an even greater prevalence of chronic bronchitis than the exposed tobacco workers, but the difference was not significant. All except one of the workers with symptoms of chronic bronchitis were smokers. For 33\% of the tobacco workers and $20 \%$ of the referents with symptoms of bronchitis, a physician had earlier diagnosed asthma or chronic bronchitis. The exposed workers had previously had atopic diseases less often than the referents (allergic rhinitis significantly less often, OR 0.14 and $95 \%$ confidence interval $(95 \% \mathrm{CI}$ ) 0.02 to 0.85$)$.

The occurrence of symptoms of alveolitis (prolonged cough, dyspnoea, or fever) was the same in the exposed $(n=12)$ and unexposed $(n=11)$ groups. There was a distinct overlapping of symptoms of alveolitis and obstructive airways disease in the two groups. In most of the workers (eight persons in both groups) with such symptoms either chronic bronchitis or asthma had been earlier diagnosed. None of the referents reported that the symptoms of alveolitis were work related. In the exposed group five of the 12 symptomatic people reported the symptoms to be work related based on algorithms of the data from the questionnaire. Two of them associated symptoms with visits to humidified departments. Three reported flu-like illness at least one to three times a month. Among four of the five people with work related symptoms, these had begun over 4 hours after the work began. The most recent episode had occurred over 1 year ago. The results of lung function tests and radiographs were normal in all five subjects. According to an additional interview with the subjects with symptoms of alveolitis, two with repeated flu-like illness had been diagnosed as 
Table 3 Lung function measurement as adjusted means

\begin{tabular}{lll}
\hline $\begin{array}{l}\text { Lung function } \\
\text { variable }\end{array}$ & $\begin{array}{l}\text { Tobacco workers } \\
(n=106)\end{array}$ & $\begin{array}{l}\text { Referents } \\
(n=106)\end{array}$ \\
\hline FVC & $3.89(3.89)$ & $4.01(3.98)$ \\
$\mathrm{FEV}_{1}$ & $3.09(3.10)$ & $3.23(3.19)$ \\
$\mathrm{FEV} \%$ & $80(80)$ & $81(80)$ \\
$\mathrm{MEF}_{50}$ & $4.03(4.03)$ & $4.06(4.01)$ \\
$\mathrm{MMEF}_{25}$ & $1.14(1.15)$ & $1.32(1.27)$ \\
$\mathrm{D}_{\mathrm{LCO}}$ & $2.93(2.95)$ & $3.15(3.07)$ \\
$\mathrm{D}_{\text {LCO }}$ VA & $8.57(8.57)$ & $8.35(8.29)$ \\
\hline
\end{tabular}

having or suspected of having chronic bronchitis, and one with immediate symptoms was strongly atopic (IgE 920) without specific sensitisation to tobacco extract or moulds.

Breathlessness on exertion, sneezing, and eye complaints were distributed evenly in both groups. Stomach symptoms and back pain, as control questions, occurred equally in both groups.

IMMUNOGLOBULIN G ANTIBODIES TO MICROORGANISMS

The group of tobacco workers had lower concentrations of the IgG antibodies to the panel of moulds used. Titres of antibodies to tobacco were higher among tobacco workers than among referents. From the point of view of the objectives of this study the results of IgG antibodies were uninformative.

\section{LUNG FUNCTION}

\section{Spirometry}

The means and adjusted means of the lung function variables are presented in table 3 . In the paired $t$ tests the tobacco workers had significantly lower forced vital capacity (FVC, $\mathrm{p}=0.04), \mathrm{FEV}_{1}(\mathrm{p}=0.02)$ and maximal expiratory flow at $25 \%$ of the FVC $\left(\mathrm{MEF}_{25}, \mathrm{p}<0.01\right)$ values than the referents. In the ANCOVA, where height and pack-years of smoking were used as covariates, no significant differences remained. As covariates, height and pack-years of smoking explained the differences in FVC and $\mathrm{FEV}_{1}$ values, only height had a significant effect. Among ex-smokers tobacco workers tended to have lower lung function values than referents, mainly because of longer and heavier previous smoking.

The tobacco workers had a significantly greater prevalence of impaired $\mathrm{FEV}_{1}$ relative to the predicted values (OR 3.5, 95\% CI 1.2 to 9.9, table 4). The tobacco workers tended to have an FVC that was more often below the predicted level (OR 2.5, 95\% CI 0.8 to 7.7 ).

\section{Diffusing capacity}

The referents had significantly lower $\mathrm{D}_{\mathrm{LCO}} / \mathrm{VA}$ values $(\mathrm{p}=0.03)$ in the paired $t$ test, but the analysis of covariance showed no significant

Table 4 Impaired lung function $\left(<2 S D\right.$ of the predicted values $\left.{ }^{\star}\right)$ in the exposed tobacco workers and unexposed referents $(n=106)$

\begin{tabular}{|c|c|c|c|c|}
\hline \multirow[b]{2}{*}{ Smoking group } & \multicolumn{2}{|l|}{$F V C$} & \multicolumn{2}{|l|}{$F E V_{1}$} \\
\hline & Tobacco workers (n) & Referents (n) & Tobacco workers (n) & Referents (n) \\
\hline Non-smokers & 3 & 2 & 5 & 1 \\
\hline Ex-smokers & 3 & 2 & 5 & 2 \\
\hline Smokers & 3 & - & 6 & 2 \\
\hline Total & 9 & 4 & 16 & 5 \\
\hline
\end{tabular}

*Predicted values by Viljanen et $a l^{3}: \mathrm{FVC}<82 \% ; \mathrm{FEV}_{1}<81 \%$ of predicted.
Table 5 Occurrence of small opacities (profusion 0/0-1/1) in the chest radiographs rated by two radiologists according to the ILO classification of pneumoconiosis

\begin{tabular}{lll}
\hline Profusion & Tobacco workers $(n=102)$ & Referents $(n=102)$ \\
\hline $0 / 0$ & 78 & 75 \\
$0 / 1$ & 15 & 19 \\
$1 / 0$ & 8 & 4 \\
$1 / 1$ & 1 & 1 \\
Total & 102 & 99 \\
\hline
\end{tabular}

difference in diffusing capacity values between the groups. Pack-years of smoking, height, and weight produced significant results in the analysis. The ex-smoking tobacco workers had a tendency towards lower $\mathrm{D}_{\mathrm{LCO}}$ values than the ex-smoking referents due to differences in their smoking habits. Atopy was involved in the model, but it did not explain the differences in any of lung function variables of spirometry or diffusing capacity.

The analysis of various combinations of history of symptoms and an impairment of lung function or mild radiographic fibrosis was performed. This analysis showed no difference between the study groups.

SKIN PRICK TESTS

The referents had more atopy indicated by positive skin prick tests to common environmental allergens (26 v 14). The tobacco workers had a significantly larger mean weal size in the skin test to Dermatophagoides pteronyssimus $(0.30 v 0.06)$. There were only a few positive skin tests to moulds, two for tobacco workers and four for referents. There were no positive skin tests to tobacco among the currently exposed tobacco workers. One kitchen worker, who had been removed from tobacco work because of allergic symptoms, was also tested. She was skin prick positive to most of the tobacco extracts.

\section{CHEST RADIOGRAPHY}

There were few radiographic findings (table 5). However, the scale of profusion in the ILO classification showed a slight excess of parenchymal changes among the tobacco workers, but the difference was not significant (OR 2.0, 95\% CI 0.6 to 6.5 ). Of the workers with small opacity profusion of $1 / 0$ or $1 / 1$, three had slightly impaired (for predicted) lung function values; two of them were smokers. Only one of them had symptoms; he had been diagnosed as having chronic bronchitis and emphysema.

QUESTIONNAIRE TO FORMER WORKERS

Of the former tobacco workers, 77 (64\%) answered the questionnaire, and six considered respiratory disorders to be one reason for their pension. There were four people who had had symptoms of prolonged cough, dyspnoea, or fever, but none of them had sought medical treatment. Usually, musculoskeletal disorders had been the most prominent complaints of the tobacco workers. One young person had changed jobs because of asthma, which had begun before his tobacco work. 


\section{Discussion}

In this study no significant difference in the prevalence of respiratory symptoms between the tobacco workers and the referents was found. The fact, that the currently smoking referents turned out to be heavier smokers than the smoking tobacco workers, may have affected the comparison of bronchitic symptoms. According to the questionnaire algorithm used ${ }^{22}$ we found five tobacco workers fulfilling the criteria of allergic alveolitis. Four of them had reported delayed onset of symptoms, two workers were able to relate their symptoms to visits to humidified departments inside the factory. More than 1 year had passed since the last episode. All workers had at a time of examination normal lung functions and chest radiographs. These cases may have been acute episodes of allergic alveolitis or humidifier fever, probably even organic dust toxic syndrome (ODTS), which has been described with the same type of symptoms ${ }^{29} 30$ There was and probably is no exact way of diagnosing past allergic alveolitis in epidemiological studies. In the absence of radiological abnormality and impairment of lung function we were unable to distinguish humidifier fever and allergic alveolitis. However, considering the exposures encountered in the cigar factory, and the necessity of humidification all mentioned disorders seem to be plausible risks for tobacco workers.

During the study it turned out that the ventilation and humidifying systems were technically improved in some departments of the factory during the year before the study. The fact, that the five workers with symptoms of alveolitis had not experienced episodes during the past year, seems to further incriminate the humidification system as the cause of symptoms.

Working in a cigar factory or exposure to tobacco dust has been suggested to affect the respiratory system; a tendency towards lower spirometric values among tobacco workers has been suspected in several studies. ${ }^{12}{ }^{14-16}$ In the crude comparison of the study groups we noted a similar tendency. However, in the multivariate analysis including pack-years of smoking and other covariates all differences in the spirometric results and in the results of diffusing capacity between the exposed and unexposed groups disappeared. It is important to notice that matching by smoking category was insufficient to control for the effect of smoking. On the other hand detailed matching according to pack-years does not seem practicable. Also other studies ${ }^{12} 15$ that took the amount of smoking into account have made the same kind of observations that differences in spirometric values are mainly accounted for by different smoking habits. Only one study has been performed among non-smoking tobacco workers; Valic et $a l^{13}$ reported acute decrements in spirometric values over a workshift, but despite the high exposure to tobacco dust (the mean total dust concentrations ranged from 0.9 to $27.5 \mathrm{mg} / \mathrm{m}^{3}$ ) no long term effects on spirometric values were found compared with the referents.
By contrast with the results of some studies $^{1519}$ we found no decrease in $D_{\text {LCO }}$ among the exposed workers. The unexpected result of a lower diffusing capacity among the referents can possibly be explained because their current smoker referents had more packyears than the tobacco workers.

On the chest $x$ ray films slight profusion indicating parenchymal changes in the lung appeared in subjects with a work history $>30$ years, similar to another study. ${ }^{15}$ However, the case with $1 / 1$ profusion had been exposed for only $12-13$ years. The number of observations was too small to draw conclusions as to whether age and smoking can affect the development of profusion.

The sample was small, but it consisted of all the cigar workers exposed to raw tobacco in Finland. Although matching is not typical with a study design such as ours, we considered it necessary. We thought that controlling for smoking would have been difficult in the analysis as few workers were examined.

Our referents reported more earlier atopic diseases, and they also more often had positive skin tests to common environmental allergens than did the tobacco workers. There was no excess of atopy among the referents, because their prevalences of atopic diseases and positive skin tests were similar to those of the general population. ${ }^{31}$ Selection has been thought to explain the fact that atopy occurs less often among workers exposed to organic dusts than among workers exposed to gases and fumes or to no irritants. ${ }^{32}$ Although selection was not directly seen in the results of the former workers, the low response rate could have led to a lack of information, and the former workers may not have reported all their reasons for stopping work. Some effects of selection, especially on comparisons of symptoms, cannot be ruled out.

\section{Conclusions}

We did not find any excesses of prevalence of chronic bronchitis and respiratory symptoms in the tobacco workers. According to the questionnaire, episodes of allergic alveolitis may have occurred in the cigar factory. However, in the absence of impairments of lung function and radiological changes it was not possible to distinguish humidifier fever and allergic alveolitis. Considering exposure conditions including humidification of the air both diseases constitute a risk for tobacco workers. We were unable to show any effect of exposure to tobacco dust on lung function; in multivariate analysis differences between the exposed and unexposed groups were mainly explained by amount of smoking, and height or weight.

This study was conducted with financial support from the Finnish Work Environment Fund and the Research Fund of the Tampere University Hospital. We also thank Professor Erkki Terho for his important aid in designing the questionnaire and Dr Jorma Seitsamo, and Professors Matti Hakama and Pekka Laippala for their statistical assistance.

1 Blair A, Berney BW, Heid MF, et al. Causes of death among workers in the tobacco industry. Arch Environ Health 1983;38:223-8. 
2 Dutciewitz J. Hypersensitivity pneumonitis in grain farmers due to sensitization to Erwinia herbicola. Allergy 1985;54: due to

3 Kotimaa M. Occupational exposure to airborne spores of fungi and actinomycetes with special emphasis on agricultural work [dissertation]. Kuopio: Kuopio University, 1990.

4 Nevalainen A, Pasanen A-L, Niininen M, et al. The indoor air quality in Finnish homes with mold problems. Environment International 1991;17:299-302.

5 Strachan DP, Flannigan B, McCabe EM, et al. Quantification of airborne moulds in the homes of children with and without wheeze. Thorax 1990;45:382-7.

6 Husman T. Health effects of indoor-air microorganisms. Scand 7 Work Environ Health 1996;22:5-13.

7 Becker CG, Dubin T, Wiedemann H P. Hypersensitivity to tobacco antigen. Proc Natl Acad Sci 1976;73:1712-6.

8 Gleich GJ, Welsh PW. Immunochemical and physicochemical properties of tobacco extracts. Am Rev Respir Dis 1979; 120:995-1001.

9 Lander F, Jepsen JR, Gravesen S. Allergic alveolitis and late asthmatic reaction due to molds in the tobacco industry. asthmatic reaction due

10 Huuskonen MS, Järvisalo J, Koskinen $\mathrm{H}$, et al. Serum angiotensin-converting enzyme and lysosomal enzymes in angiotensin-converting enzyme and lysos

11 Tukiainen P, Huuskonen MS, Keskinen H, et al. Alveolar macrophage reaction induced by grain and tobacco dusts. In: Abstracts, XXII International Congress on Occupational Health: work for health, 27 September-2 October 1987. Sydney, Australia: ICOH, 1987:135.

12 Kjaergaard SK, Pedersen OF, Frydenberg M, et al. Respiratory disease and lung function in a tobacco industry. Arch Environ Health 1989;44:164-70.

13 Valic F, Beritic D, Butkovic D. Respiratory response to tobacco dust exposure. Am Rev Respir Dis 1976;113:751-5.

14 Ghosh SK, Parikh JR, Gokani V N, et al. Occupational health problems among tobacco processing workers: a prehealth problems among tobacco processing workers: a pre-

15 Viegi G, Paggiaro P L, Begliomini E, et al. Respiratory effects of occupational exposure to tobacco dust. Br f Ind effects of occupation

16 Mukhtar MSR, Rao GMM , Gamra NS, et al. Respiratory effects of occupational exposure to tobacco dust. Respiration 1991; 58:271-6.

17 Lander F, Gravesen S. Respiratory disorders among tobacco workers. Br F Ind Med 1988;45:500-2.
18 Kjaergaard SK, Pedersen OF. Dust exposure, eye redness, eye cytology, and mucous membrane irritation in a tobacco industry. Int Arch Occup Envron Health 1989;61:519-25.

19 Huuskonen MS, Husman K, Järvisalo J, et al. Extrinsic allergic alveolitis in the tobacco industry. $\mathrm{Br} \mathcal{F}$ Ind Med 1984;41:77-83.

20 Uitti J, Kotimaa M, Roto P, et al. Tupakkatyöntekijöiden altistuminen home- ja sädesienten itiöille ja gram-negatiivisille bakteereille sekä sairastavuusalveoliittiin (Exposure to microbes and the prevalence of allergic alveolitis in the Finnish tobacco industry). Helsinki:Finnish Institute of Occupational Health. Research report for the Finnish Work pational Health. Research

21 Medical Research Council. Questionnaire on respiratory symptoms: instructions to interviewers. London: MRC, 1986.

22 Terho EO, Husman K, Vohlonen I. Prevalence and incidence of chronic bronchitis and farmer's lung with respect to age, sex, atopy, and smoking. Eur F Resp Dis 1987; 71(suppl): 152 .

23 American Thoracic Society. Standardization of spirometry. Am Rev Respir Dis 1987;136:1299-307.

24 Vilianen A. Reference values for spirometric, pulmonary diffusing capacity and body plethysmographic studies. Scand f Clin Lab Invest 1982;42(suppl): 159.

25 Make B, Miller A, Epler G, et al. Single breath diffusing capacity in the industrial setting. Chest 1982;82:351-6.

26 Cotes JE. Lung function: assessment and application in medicine, 3rd edition. Oxford: Blackwell, 1975.

27 Haahtela T, Björksten F, Heiskal M, et al. Skin prick test reactivity to common allergens in Finnish adolescents. Allergy 1980;35:425-31. 28Guidelines for the use of ILO international classification of radiographs of pneumoconioses. Geneva: International Labour Office, 1980. (Occupational safety and health series, No 22.)

29 do Pico GA. Report on diseases. Am f Ind Med 1986;10:261-5.

30 Rylander R. Lung diseases caused by organic dusts in the farming environment. Am $\mathcal{F}$ Ind Med 1986;10:221-7.

31 Sub-Committee on Skin Tests of the European Academy of Allergology and Clinical Immunology. Skin tests used in type I allergy testing: position paper. Allergy 1989; 44(suppl): 10

32 Chan-Yeung $M$, Vedal S, Lam S, et al. Immediate skin reactivity and its relationship to age, sex, smoking, and occupational exposure. Arch Environ Health 1985;40:53-7. 